\title{
Vankka annos esimerkkejä ja kokemuksia mentoroinnista
}

\author{
Tuulikki Juusela - Tuula \\ Lillia - Jari Rinne \\ (2000). Mentoroinnin \\ monet kasvot. \\ YRITYSKIRJATRY
}

\section{Tällä kirjalla on hyvä} nimi. Hyvä se on siksi, että viime aikoina vahvasti eräänä henkilöstön kehittämismuotona esiinnoussut mentorointi sisältää monia erilaisia sovellusmahdollisuuksia. Mikä tahansa kahden ihmisen säännöllinen keskustelu - jollaisesta mentoroinnissa on kysymys - ei silti ole mahdutettavissa yleisnimikkeen alle. Se ei ole perehdyttämistä, työnopastusta, valmentamista eikä työnohjausta. Tämä tuodaan kirjassa selkeästi ja hyvin esille.

\section{Mentoroinnin moni-} kasvoisuutta esitellään kirjan teoriaosassa monipuolisesti. Monet käytännön esimerkit tarjoavat hyödyntämismahdollisuuksia niille kohderyhmille ja henkilöille, joille kirja soveltuu:

\section{Osaamispääoman pysy-} vyydestä huolta kantaville yritysten ja organisaatioiden esimiehille, henkilöstöjohto mukaan luettuna.

Mentorin rooliin suostuvalle kokeneelle, kommunikointikykyiselle ja avoimelle henkilölle.

Aktorin (oppijan) asemaan pyrkivälle, omasta henkisestä ja ammatillisesta kasvustaan kiinnostuneelle. Kirjoittajat itse käyttävät usein sanaa

\begin{abstract}
"mentoroitava", joka tuo ensisijaisesti mieleen taikinan alustamisen. Siitähän ei kuitenkaan saisi olla kysymys, koska aktorin oma-aloitteisuus ei tule selvästi esille. Kirjassa myönnetäänkin termin heikkous ja haastetaan lukijat keksimään tilalle parempi suomenkielinen sana.

Liian usein ohjelmissa unohdetulle aktorin esimiehelle, jota luonnollisesti kuitenkin kiinnostaa alaisensa kehittyminen. Mentori ei korvaa esimiestä tai ota vastuuta alaisen suorituksesta.
\end{abstract}

\section{Teoriaosa tarjoaa ylen-} palttisesti neuvoja ja ohjeita kaikille mentoroinnista kiinnostuneille, josta esimerkkinä muistilista aktoreille:

Tee henkilökohtainen kehittymis- ja oppimissuunnitelma

- Ota esiin ongelmia (ratkaisut sinun on kuitenkin löydettävä itse!)

Tartu heikkouksiisi Älä pelkää virheitä; "ne ovat oppimisen paikkoja" Tarkastele elämääsi pitkällä aikavälillä

Esitä myös hulluja ideoita

\section{Nämä ovat käyttö-}

kelpoinen lähtökohta kahdenkeskiselle, aidolle ja luottamukselliselle, joustavalle sekä molemminpuolista sitoutumista edellyttävälle vuorovaikutukselle. On tietysti muistettava, että mentorointi on ainutkertainen tapahtumasarja, johon sisällön luovat kaksi erilaista, samaan päämäärään pyrkivää henkilöä vahvuuksineen ja heikkouksineen.

\section{On tärkeää, että - usein} jo seniori-ikäinen - mentorikin tuntee saavansa itselleen uutta ja voivansa kokea iloa aktorin kehittymisestä. Se, miten syvällisesti keskustellaan työelämän ulkopuolisista asioista, riippuu täysin keskinäisestä luottamuksesta ja avoimuudesta. "Hyvä mentori on valmis jakamaan osaamistaan ja elämänkokemustaan ja saa vahvistusta siihen, että maailma on hyvissä käsissä hänen jälkeensäkin”.

Kirjassa on runsaasti esimerkkejä ja kokemuksia suomalaisessa työelämässä toteutetuista ohjelmista, mentorikokemuksista ja mentori-aktori-parityöskentelystä. Tunnetuimpia näistä yrityksistä ovat Merita-Nordbanken ja Suomen Posti, joissa mentorointi on otettu laajasti käyttöön jo muutamia vuosia sitten. Heidän ohjelmansa ovat tuottaneet hyviä tuloksia ja ovat pysyvä osa henkilöstön kehittämistä. Tieto Enatorin sovellus on hyvä kuvaus uuden systeemityömallin sisäänajosta, jossa mentorointia on käytetty vaikeassa muutostilanteessa hyväksi. Espoon kaupunki on käynnistänyt erityisen seniorimallin, jonka perusajatuksena on, että työyhteisössä arvostetaan ikääntyneen henkilöstön kokemusta, 
työtaitoja ja laaja-alaisuutta, joka antaa mentoreina toimiville henkilöille mahdollisuuden uuden oppimiseen, koulutukseen ja työssä kehittymiseen. Teknokummit eli kokeneet liikkeenjohtajat toimivat uusien yritysten neuvojina ja sparraajina niiden kasvutilanteissa, kansainvälistymisprosesseissa ja liiketoiminnan solmutilanteissa. Myös muutamat henkilökohtaiset kokemukset (Tuulikki Petäjäniemi, Pirkko Saarikivi, Kalevi Liukkonen) ovat mielenkiintoista luettavaa niille, joilla on jo omia kokemuksia mentoroinnista tai jotka haluaisivat ryhtyä mentoreiksi. Aina voi toisten kokemuksista oppia jotain uutta.

\section{Mentoroinnin}

soveltaminen yrityksissä, järjestöissä, yliopistoissa ja korkeakouluissa sekä julkishallinnossa on usein alkanut kokeiluohjelmana, josta hankitaan tietoa ja kokemusta ennen kuin sitä toteutetaan laajemmin. Useimmat kokemukset ovat positiivisia, joten mentoroinnista on tullut Suomeen eräs pysyvä ja monia mahdollisuuksia tarjoava henkilöstön kehittämismuoto, nuorten urakehityksen vauhdittaja ja uusien yrittäjien ohjauskeino.

Kirja tarjoaa riittävästi teoreettista tietoa mentoroin- nista, monia erilaisia esimerkkejä ja kokemuksia mentoroinnin aloittamiseen ja soveltamiseen. Kokeneet ja mentoroinnissa mukana toimivat henkilöt saavat enemmän irti kirjan opeista ja sovelluksista kuin esimiehet ja ne, jotka eivät vielä ole asiaan perehtyneet. Kirjan anti olisi ollut parempi lukijan kannalta, jos kirjassa olisi tiivis yhteenveto teoriaosasta ja mukaan olisi valittu vain parhaat mentorointiesimerkit ja kokemukset.

\section{Reijo Maunula ja} Veikko Sipola 